\title{
Agri-food trade trends in Papua New Guinea Reflections on COVID-19 policies and dietary change
}

\author{
Emily Schmidt and Peixun Fang
}

The onset of the COVID-19 pandemic has presented a unique challenge to governments across the globe, reinforcing the need to improve understanding of domestic and international trade trends to provide more informed options for policy response. Papua New Guinea's growing international trade in food and other agricultural products will continue to be important to overall food security outcomes among rural and urban households in the country. Rural households that produce key export cash-crops, such as coffee, cocoa, or palm oil, depend on the cash economy to supplement their food consumption, while urban households depend on rice and other agri-food imports, as well as domestic goods, for consumption.

This project note focuses on trends in agrifood imports and exports during the last two decades to better evaluate potential changes in import demand and export potential for PNG. In doing so, it informs an upcoming economy-wide multi-market model analysis that will evaluate a variety of potential shocks to PNG's agri-food system on household welfare in order to identify policies to manage potential food security threats. The COVID-19 pandemic is one of many diverse shocks that may adversely affect the economy of PNG over the next decade. The expansion of a portfolio of organized databases, analytical tools, and policy resources, such as the multimarket model, is warranted to facilitate real-
Key Policy Messages

- The COVID-19 pandemic presents a new challenge of tracking and containing disease spread, while managing and facilitating the movement of tradeable goods within Papua New Guinea.

- Agri-food imports are contributing to increases in the availability of proteindense foods - poultry imports, for example, grew by 30 percent per capita per year from 2001 to 2016.

- However, imports of sugary soft drinks have increased by almost 12 percent per capita per year since 2001, the largest growth in processed agri-food imports over this period.

- Government policies to facilitate domestic movement of goods, as well as macro-economic policies, such as those around real exchange rates, should be managed to support agrifood production and trade. These policies could be paired with nutritionsensitive education programs to reduce consumption of processed foods that are high in sugar and saturated fat, for which total import values are now rapidly increasing. 
time policy analyses to inform key development investments and initiatives.

Agri-food imports in PNG have expanded both healthy and unhealthy food consumption patterns. For example, agri-food imports of protein-rich, animal-source foods have grown by 8 percent per capita per year since 2001 . This is a positive transition given that PNG has a limited livestock sector and low levels of protein consumption across both poor and non-poor households (Schmidt et al. 2019). However, agri-food imports of sugary soft drinks have increased by almost 12 percent per capita per year since 2001, representing the largest growth in processed agri-food imports over the analysis period.

\section{Real exchange rate appreciation and incentives for PNG's agricultural trade}

Although a large share of economic growth in PNG has been through the extractive industries sector, agriculture is the principal sector of employment for 80 percent of the rural population. PNG continues to develop its agri-food export potential through investments in cocoa, coffee, and palm oil, resulting in PNG being a net exporter of agricultural goods. Within this trade environment, macroeconomic policies are important to incentivize farmers of export crops to increase their agricultural output.

To a large extent, PNG has avoided major exchange rate and price distortions through careful management of macro-economic policy. Nonetheless, domestic inflation outpaced depreciation of the nominal exchange rate so that the real exchange rate, a measure of the relative prices of tradable goods to non-tradable goods, appreciated by about 20 percent between 2010 and 2019

(Figure 1). In particular, the nominal exchange rate depreciated by 24.6 percent, from 2.72 to 3.39 PNG Kina per US dollar during this period. At the same time, the Consumer Price Index (CPI) for PNG, a measure of domestic inflation and increases in the price of nontradables, rose by 56.0 percent. Thus, the nominal exchange rate deflated by the PNG consumer price index, fell by 20.1 percent. This figure approximates the real exchange rate depreciation for PNG calculated by the IMF, which takes into account changes in international prices of tradables and a broader average of country exchange rates.

Thus, as a result of this real exchange rate depreciation, export-oriented agriculture has tended to become less profitable per unit of production in real terms over the last decade. If the real exchange rate is not managed properly, farmer incentives to produce export crops may decrease further, resulting in falling total production and export volumes.

Figure 1: PNG nominal and real exchange rates $(2010=100), 2010$ to 2020

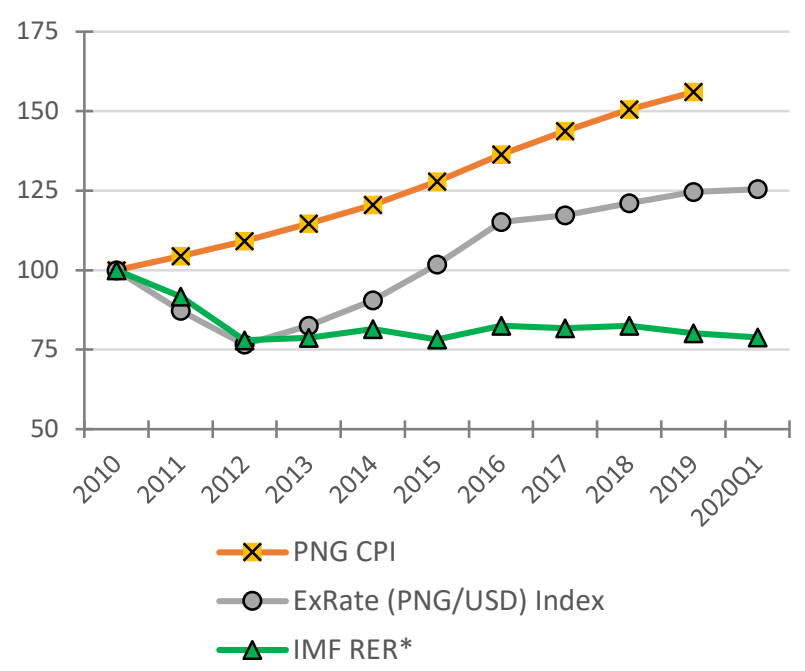

Source: Authors' calculations from IMF International Financial Statistics data. $\mathrm{CPI}=$ Consumer Price Index; RER = Real exchange rate

Appropriate non-price distorting PNG government interventions, such as investments in roads, electricity, and ports, can help address the disincentives faced by PNG producers and firms engaging in agricultural trade. However, despite these disincentives, PNG has experienced growth in its agri-food trade between 2001 and 2016, with agri-food exports increasing by 8 percent, and imports increasing by 13 percent.

\section{Overview of PNG agri-food exports}

Overall, PNG is a net exporter of agri-food products - in 2016/17 agri-food exports amounted to 1.26 billion USD compared to 
agri-food imports of 0.81 billion USD. Agrifood trade continues to increase and comprises over 10 percent of PNG's total export earnings. In terms of value, palm oil exports experienced the largest increase, growing on average 9 percent per year (real 2014 USD) from 2001 to 2016 (Figure 2). Coffee and cocoa bean exports grew by 4 percent per year on average between 2001 and 2016. These increases in cash-crop exports are reflected in changes in agricultural production patterns across the country over the same period.

Figure 2: Largest agri-food exports by average annual value, 2001-05 and 2012-16

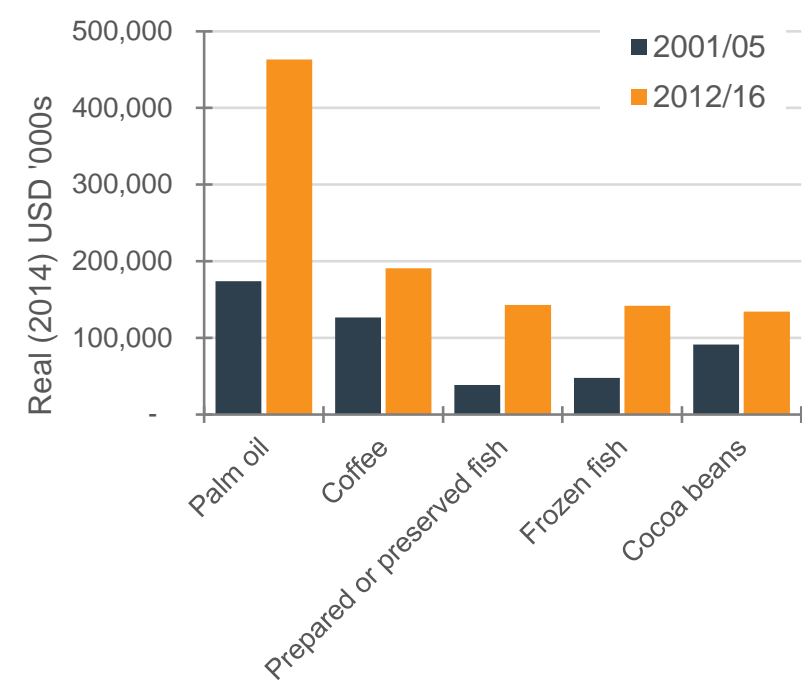

Source: Authors' calculations using BACI International trade database at the product level (2019)

The shift towards export-oriented agri-food production has benefitted both large commercial farming operations and smallholder farmers. Smallholder farmers accounted for over 85 percent of coffee production in PNG in 2012 (Aipi 2012). Approximately 20 percent of the rural labor force is engaged in smallholder cocoa production, which comprises 90 percent of total national cocoa output (World Bank 2014).

Maintaining market functionality along each link in domestic agri-food value chains is critical to ensure the food security of farmers that depend on the cash economy for their livelihood. Social distancing and quarantine policies are important for containing virus spread. However, policy regulations with regards to COVID-19, as well as African Swine Flu, have significantly affected domestic trade and the movement of both people and goods within rural areas. To maintain economic buoyancy in areas of rural PNG that focus on cash-crop production, mechanisms should be established to maintain safe, but unhindered marketing of agri-food goods from rural to urban areas.

\section{Overview of PNG agri-food imports}

Agri-food imports comprised 14 percent of total imports between 2012 and 2016 and are important to maintaining food security and supporting dietary diversity in Papua New Guinea. Rice imports made up the largest share (15 percent) of overall agri-food imports on average over this period.

Figure 3: Annual value and quantity of poultry imports, 2005 to 2016

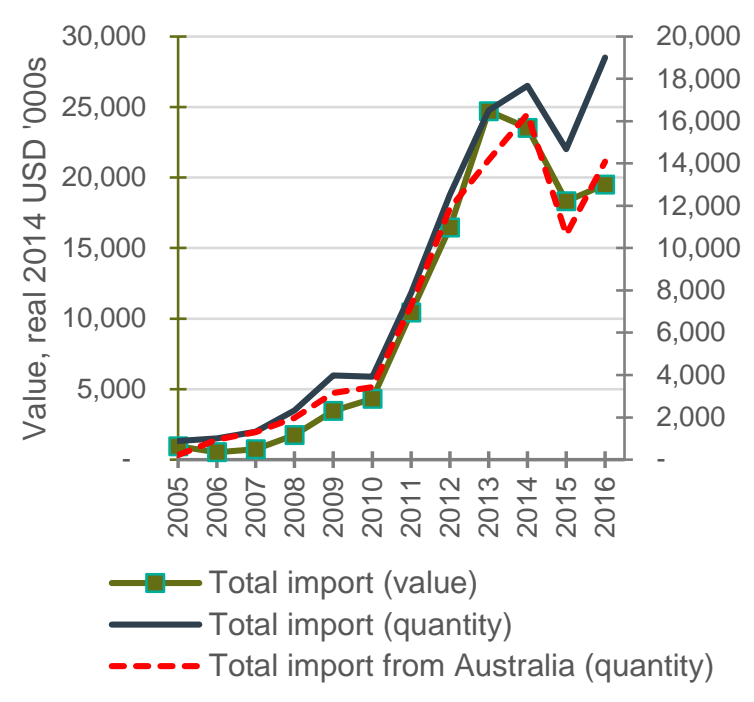

Source: Authors' calculations using BACI International trade database at product level.

Growth in other agri-food imports reflects a shift in demand towards increased consumption of protein-rich foods. The value of annual poultry imports, primarily from Australia, increased more than 30-fold between 2001-05 and 2012-16, albeit from a low base (Figure 3; Table 1). Preserved and prepared fish imports increased by 21 percent per capita per year between 2001 and 2016, with Thailand supplying the largest share in the form of tinned mackerel for domestic consumption. Tinned mackerel is less 
Table 1: Top ten agri-food imports over period 2012 to 2016, average annual value between 2001 and 2005 and between 2012 and 2016

\begin{tabular}{|c|c|c|c|}
\hline Agri-food imports & $\begin{array}{c}\text { 2001-05, } \\
\text { real 2014 } \\
\text { USD '000s }\end{array}$ & $\begin{array}{l}\text { 2012-16, } \\
\text { real 2014 } \\
\text { USD '000s }\end{array}$ & $\begin{array}{c}\text { annual growth } \\
\text { per capita, \% }\end{array}$ \\
\hline Rice & 76,237 & 119,513 & 1.9 \\
\hline Sheep / goat meat & 30,837 & 60,232 & 3.9 \\
\hline Bottled waters & 2,529 & 58,838 & 30.2 \\
\hline Wheat, including wheat flour & 11,307 & 57,463 & 13.4 \\
\hline Food preparations** & 10,669 & 56,813 & 13.9 \\
\hline Preserved / prepared fish & 2,967 & 30,198 & 20.8 \\
\hline Palm oil & 2,807 & 23,018 & 18.4 \\
\hline Animal feed preparations & 7,168 & 21,886 & 8.3 \\
\hline Pasta & 1,080 & 20,793 & 28.0 \\
\hline Poultry & 649 & 20,593 & 33.9 \\
\hline Sub-total of top 10 & 146,250 & 469,348 & 8.7 \\
\hline Total value of agri-food imports & 268,373 & 798,370 & 8.0 \\
\hline Top ten commodities as share of all agri-food imports, $\%$ & 54.5 & 58.8 & \\
\hline
\end{tabular}

Source: Authors' calculations using BACI International trade database at product level.

expensive than the tinned tuna that PNG produces, which is directed towards the export market.

Import data also suggest that domestic availability of animal-source protein is increasing, given that the annual quantity of animal feed preparations imported increased from about 18,000 tons between 2001 and 2005 to about 50,000 tons between 2012 and 2016. The total value of imported animal feed increased 11 percent per year on average over the same period.

PNG has a small livestock sector with few bovines or small ruminants, but with concentrations of pig husbandry in the Highlands Region. Consequently, increases at a rate of 7 percent annually in imports per capita of non- or minimally-processed meat is a positive change for increasing the protein content in diets across PNG. Analysis from the 2018 IFPRI Rural Household Survey on Food Systems in PNG suggests that the protein content of the diets of both poor and non-poor households is seriously deficient (Schmidt et al. 2019). A variety of studies evaluating protein consumption and dietary diversity have linked stunting rates to protein deficiency and a consequent lack of essential amino acids in young children (e.g., Ghosh 2016).

\section{Trade in processed foods}

We classify PNG's food imports by their level of processing using the NOVA classification system (Monteiro et al. 2019):

1. Minimally processed or unprocessed;

2. Processed culinary ingredients, e.g. oil, sugar;

3. Processed food, e.g., preserved vegetables, fruit, fish, or meat; and

4. Ultra-processed foods, e.g., pasta, sausages.

Minimally processed foods (level 1 ) are treated to ensure stability during transport. We consider food imports to be processed if they fall into categories 2 to 4 . Processed foods accounted for 50 percent of total agri-food imports between 2012 and 2016 in PNG.

Increasing demand for processed food has both positive and negative externalities. For example, purchasing processed food often saves time and labor in food production and preparation, particularly for female household members. However, greater access to ultraprocessed food can introduce unhealthy overconsumption of foods with high levels of fat, 
salt, and sugar, leading to associated nutritional challenges and higher prevalence of obesity and non-communicable diseases, such as diabetes. Ultra-processed foods comprised almost 64 percent of processed food imports into PNG in 2016, with the rate of importation of such foods by value increasing by 14 percent per capita per year between 2001 and 2016. Ultra-processed foods experienced the largest growth in imports among all categories of processed foods over this period, albeit from a low base.

Figure 4: Non-alcoholic drink imports, \% share by type, 2001-05 and 2012-16

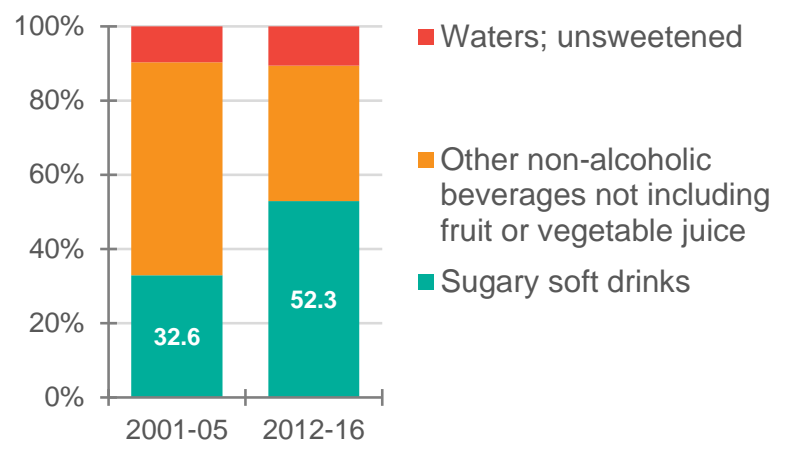

Source: Authors' calculations using BACI International trade database at product level.

The largest growth in processed foods in terms of value imported occurred in nonalcoholic drinks, growing 30 percent per capita per year between 2001-05 and 2012-16. Within the non-alcoholic drink category, the largest growth in imports was for sugary soft drinks, e.g., cola, etc. While in 2001-05, sugary soft drinks comprised about 33 percent of value of non-alcoholic imports, by 2012-16, sugary soft drinks comprised more than half of the value of non-alcoholic drinks imported (Figure 4) and 8 percent of total processed food imports.

Based on the 6-digit Harmonized System (HS) codes in the BACl dataset, we further disaggregate ultra-processed foods into sweet foods, high-saturated fat foods, and alcohol. Figure 5 shows that the value of PNG imports of processed foods increased substantially from under 100 million USD (real 2014) to over 400 million USD between 2001 and 2016. Within the ultra-processed food categories, the value of sugary food imports increased by 18 percent per capita per year, while imports of foods high in saturated fats increased 12 percent per capita per year.

Figure 5: Annual value of processed food imports, 2001 to 2016

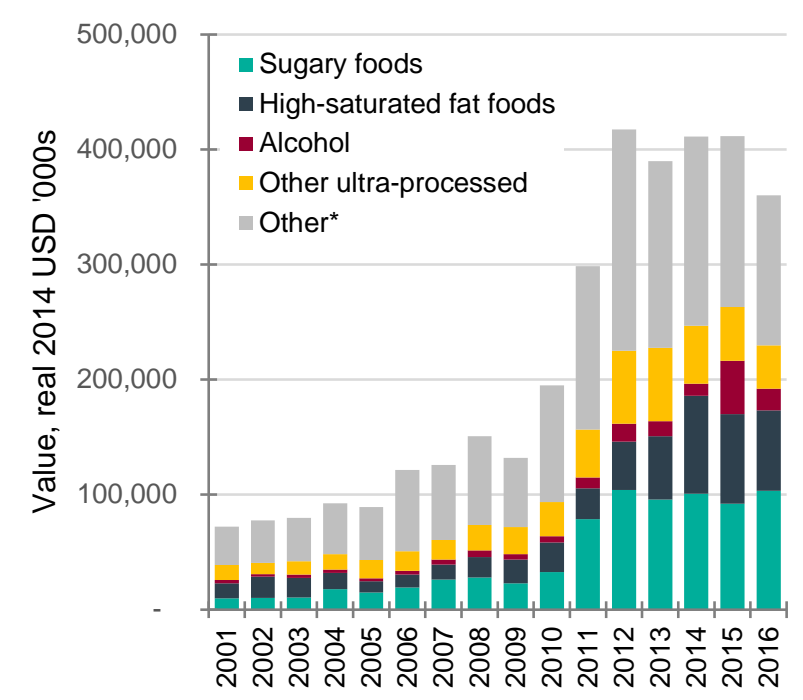

Source: Authors' calculations using BACI International trade database at product level.

Note: "Other ultra-processed" includes tobacco products, pasta, packaged soups/sauces, etc.

"Other" is equivalent to imports of processed culinary ingredients (level 2, e.g., oil, sugar) and basic processed foods (level 3, e.g., preserved vegetable/fruit).

Comparing PNG's ultra-processed agrifood imports to other countries in the Pacific using the same food category types suggests that greater education on dietary consumption choices may be necessary, especially for periurban and urban populations. About 32 percent of the value of PNG's processed agrifood imports were ultra-processed. PNG ranks sixth among 14 Pacific nations for the share of its total imported processed foods by value made up by ultra-processed foods.

Among PNG's imports of ultra-processed agri-foods, sugary foods are the largest share, comprising 38 percent. A variety of studies have associated soft drink consumption with increased obesity rates among children and adults, including a recent study by Kessaram et al. (2015) focusing on Pacific island youth. Benjamin (2007) and Pus et al. (2016) echo this, both warning that overweight and obesity is a growing health concern in urban areas of PNG. 


\section{Conclusions}

Between 2001 and 2016, Papua New Guinea increased its overall agri-food imports and exports by 10 and 6 percent per year, respectively. Agriculture remains an important sector of the economy with agri-food exports comprising over 10 percent of total export earnings. However, the COVID-19 pandemic and associated domestic and international policies are disrupting trade flows both within PNG and between PNG and other countries.

To maintain agricultural output among farmers export crops and to ensure food security among rural and urban populations within PNG, it is important that domestic trade, marketing, and the mobility of both foodstuffs and traders is secure, facilitated, and safe with appropriate social distancing measures to reduce virus spread. Outside of the COVID-19 pandemic, macro-economic policies, e.g., exchange rate policies, should be reviewed to ensure that the export-oriented agricultural production of smallholder farmers remains economically vibrant and sufficiently attractive financially to incentivize farmer to invest in yield-enhancing technologies.

Previous studies have found that increases in household income in developing countries are often associated with increases in demand for higher-value food items, particularly for protein-dense and more processed foods. The analysis presented here suggests that the demand for a more diversified diet is increasing in PNG, potentially bringing greater access to animal-source foods via imports and greater domestic livestock production. However, these potential gains in dietary diversity could be diminished if goods are unable to reach markets in a timely manner or price shocks due to market inefficiencies and trader immobility cause domestic and imported goods to be financially infeasible for consumption by rural or urban households.
Although PNG's agri-food import data suggest growing demand by households for a diversified food consumption basket, with increases in protein-rich foods, in particular, there are signs that such improvements in dietary diversity could be side-tracked by parallel growing demand for foods that are high in sugar and saturated fats, particularly among urban and peri-urban populations with greater access to markets. Sugary soft drinks was the processed food type with the largest increase in value of imports between 2001-05 and 2012-16, increasing by 12 percent per capita per year.

Garcia-Dorado et al. (2019) argue that improved terms of trade do not fully explain increases in demand for ultra-processed foods, but rather foreign direct investment and its links to marketing of unhealthy foods are also driving growing consumption of such foods in low and middle-income countries. Thow (2009) argues for greater participation of public health nutritionists in trade policy decision-making.

Education programs that integrate nutrition and diet information will be important to curb the growing prevalence of both obesity and diabetes in urban areas of PNG found in recent studies. These programs should not only be targeted to children in primary and secondary school, but also to caretakers and other adults, female and male, who are the primary decision-makers within households on food expenditure and meal preparation.

Finally, Snowdon et al. (2013) identify the need for legislation and enforcement of good quality food safety and nutrition labelling throughout the Pacific islands, including PNG, to curb the increasing incidence of noncommunicable diseases related to obesity and over-nutrition. 


\section{References}

Aipi, B. 2012. Supply Response of Coffee in Papua New Guinea. Bank of Papua New Guinea - Working Paper Series. 2012/01.

Benjamin, A.L. "Body size of Papua New Guineans: A comparison of the body mass index of adults in selected urban and rural areas of Papua New Guinea." PNG Medical Journal. 50(3-4):163-171.

García-Dorado, S.C., L. Cornselsen, R. Smith, and H. Walls. 2019. "Economic globalization, nutrition and health: A review of quantitative evidence." Globalization and Health. 15(1): 15.

Ghosh, S. 2016. "Protein quality in the first thousand days of life." Food and Nutrition Bulletin. 37(1): S14S21.

Guillaume, G. and S. Zignago. 2010. BACI: International Trade Database at the Product-Level. The 19942007 Version. CEPII Working Paper 2010-23.

Kessaram, T., J. McKenzie, N. Girin, O.E.A. Merilles, J. Pullar, A. Roth, P. White, and D. Hoy. 2015. "Overweight, obesity, physical activity and sugarsweetened beverage consumption in adolescents of Pacific islands: Results from the Global SchoolBased Student Health Survey and the Youth Risk Behavior Surveillance System." BMC Obesity, 2(1): 34.
Monteiro, C.A., G. Cannon, M. Lawrence, M.L. Costa Louzada, and P. Pereira Machado. 2019. Ultraprocessed foods, diet quality, and health using the NOVA classification system. Rome, Food and Agriculture Organization of the United Nations.

Pus, A., M. Moriyama, M. Uno, and M Rahman. 2016. "Identifying factors of obesity in Papua New Guinea: A descriptive study. Health. 08: 1616-1629.

Schmidt, E., R. Gilbert, B. Holtemeyer, G. Rosenbach, and T. Benson. 2019. Papua New Guinea Survey Report: Rural Household Survey on Food Systems. IFPRI Discussion Paper 01801. Washington DC.

Snowdon, W., A. Raj, E. Reeve, R.L. Guerrero, J. Fesaitu, K. Cateine, and C. Guignet. 2013. "Processed foods available in the Pacific Islands.:" Globalization and Health, 9(1): 53.

Thow, A.M. 2009. "Trade liberalisation and the nutrition transition: Mapping the pathways for public health nutritionists." Public Health Nutrition, 12(11): 21502158.

World Bank and International Finance Corporation. 2014. The Fruit of Her Labor: Promoting GenderEquitable Agribusiness in Papua New Guinea. Washington, DC.

\section{ABOUT THE AUTHORS}

Emily Schmidt is a Research Fellow in the Development Strategy and Governance Division (DSGD) of the International Food Policy Research Institute (IFPRI), based in Madrid, Spain. Peixun Fang is a Research Analyst in DSGD of IFPRI, based in Washington, DC.

\section{ACKNOWLEDGMENTS}

We thank the Department of Foreign Affairs and Trade of the government of Australia and the CGIAR Research Program on Policies, Institutions and Markets for funding and facilitating the work undertaken to produce this report. We also would like to acknowledge the comments and suggestions received from the Australia High Commission in Port Moresby to improve earlier versions of this note. 